\title{
Perancangan Sistem Akuntansi Penjualan UD. Galansa Graha Motor Mayang Jember
}

\section{Siti Fatimatuz Zahro}

Jurusan Manajemen, Fakultas Ekonom dan Bisnis, Universitas Muhammadiyah Jember, Jawa Timur, Indonesia

\section{A R T I C L E I N F O}

\section{Article history:}

Received 19 May 2019

Received in revised form

16 June 2019

Accepted 15 July 2019

Available online 26 August 2019

\section{Kata Kunci:}

Sistem Akuntansi Penjualan

dan Penjualan

Keywords:

Sales Accounting System and Sales

\begin{abstract}
A B S T R A K
Penjualan dalam sebuah perusahaan memerlukan pengelolaan yang baik. Pengelolaan perusahaan yang kurang baik akan merugikan perusahaan karena dapat berimbas pada perolehan laba, dan pada akhirnya dapat mengurangi pendapatan. Penelitian ini bertujuan untuk mengetahui sistem akuntansi penjualan yang diterapkan UD. Galansa Graha Motor Mayang Jember, serta mengaplikasikan rancangan sistem akuntasi penjualan pada UD. Galansa Graha Motor Mayang Jember. Jenis penelitian yang digunakan adalah penelitian deskriptif kualitatif. Data penelitian berupa data primer dan data sekunder. Analisis data dilakukan dengan analisis deskriptif kualitatif atas sistem akuntansi penjualan pada UD. Galansa Graha Motor Mayang Jember. Hasil penelitian menyatakan bahwa UD. Galansa Graha Motor Mayang Jember masih menjalankan sistem akuntansi penjualan secara manual dan dinilai belum memadai. Perancangan sistem akuntansi penjualan pada UD. Galansa Graha Motor Mayang Jember dilakukan dalam rangka meningkatkan efisiensi dan memenuhi perkembangan aktivitas perusahaan yang semakin kompleks. Perancangan sistem akuntansi penjualan antara lain berupa perancangan struktur organisasi perusahaan, penyusunan prosedur penjualan tunai, dan pembuatan dokumen dan formulir.
\end{abstract}

\section{A B S T R A C T}

Sales in a company require good management. Poor management of the company will be detrimental to the company because it can have an impact on profitability, and ultimately can reduce revenue. This study aims to determine the sales accounting system applied by UD. Galansa Graha Motor Mayang Jember, as well as applying the design of the sales accounting system at UD. Galansa Graha Motor Mayang Jember. The was descriptive qualitative research. The data was in form of primary data and secondary data. Data analysis was carried out by qualitative descriptive analysis of the sales accounting system at UD. Galansa Graha Motor Mayang Jember. The results of the study stated that UD. Galansa Graha Motor Mayang Jember still runs a sales accounting system manually and is considered inadequate. Designing a sales accounting system at UD. Galansa Graha Motor Mayang Jember is carried out in order to increase efficiency and fulfill the development of increasingly complex corporate activities. The design of a sales accounting system includes the design of a company's organizational structure, the preparation of cash sales procedures, and the making of documents and forms.

\footnotetext{
* Corresponding author.

E-mail addresses: zahrositif@gmail.com (Siti Fatimatuz Zahro)
} 


\section{Pendahuluan}

Kondisi persaingan bisnis saat ini dinilai sangat ketat dimana perusahaan dituntut untuk mampu bertahan dan memenangkan kompetisi. Setiap jenis bidang usaha memiliki kompetitor yang keseluruhannya berorientasi untuk mendapatkan laba, kondisi ini akan mendorong perusahaan mengoptimalkan tingkat penjualannya. Penjualan menjadi tulang punggung perusahaan khususnya perusahaan dagang dalam mengembangkan usaha dalam rangka memperoleh lebih banyak keuntungan. Penjualan dalam sebuah perusahaan memerlukan pengelolaan yang baik. Salah satu bentuk pengelolaan penjualan perusahaan adalah melalui penerapan sistem akuntansi yang dinilai bermanfaat mempercepat proses pengolahan data transaksi, selain itu teknologi sistem akuntansi mampu memberikan jaminan keamanan dan keakuratan data. Setiap perusahaan memiliki sistem berbeda dalam pengelolaan penjualannya. Secara umum perusahaan harus memiliki sistem yang tepat dalam semua aspek yang dijalankannya. Sistem yang baik ini merupakan salah satu kunci dalam pengendalian (Herdianti, 2012).

Sistem akuntansi merupakan sistem formal yang utama dalamkebanyakan perusahaan. Mulyadi (2014) mendefinisikan sistem akuntansi adalah sistem yang dirancang untuk menyediakan informasi keuangan bagi manajemen melalui koordinasi organisasi formulir, catatan dan laporan. Sistem akuntansi dijalankan dengan tujuan diantaranya memperbaiki pengendalian intern, memperbaiki informasi yang lebih baik, mengurangi biaya tata usaha atau biaya administrasi, dan menentukan pelaksanaan proses produksi agar lebih mudah menjalankan perencanaan dan mencegah pelaksanaan operasional perusahaan yang kurang sehat. Di sisi lain sistem akuntansi, dapat menjadi alat kontrol perusahaan dalam menyelamatkan harta kekayaan perusahaan.

Sistem akuntansi dalam penerapannya mengarah pada pengendalian intern. Sistem akuntansi menyediakan informasi bagi para pemakainya baik sebagai pihak intern maupun pihak ekstern perusahaan.Perusahaan menjalankan kebijakan dan prosedur-prosedur atau pengendaliannya untuk menjaga keakuratan informasi dan memastikan bahwa sistem dapat beroperasi dengan baik. Kebijakan dan prosedur ini merupakan bagian dari keseluruhan struktur pengendalian intern suatu perusahaan. Pengendalian intern dalam suatu sistem informasi meliputi struktur organisasi, metode umum yang dikoordinasikan untuk mencapai suatu tujuan.

Seorang manajer dalam rangka menunjang kegiatan penjualan sangat berkepentingan atas informasi yang berkaitan dengan penjualan, untuk menyajikan informasi mengenai penjualan sehingga dapat digunakan untuk mengambil keputusan lebih lanjut. Tercapainya efektivitas kegiatan penjualanakan mempengaruhi pencapaian tujuan perusahaan sesuai dengan apa yang telah direncanakan. Hal ini memerlukan adanya pengendalian internal yang dijalankan agar kegiatan operasi berjalan dengan efektif dan efisien serta menjamin adanya keandalan mengenai catatan laporan keuangan.Pengendalian intern sangat besar pengaruhnya atas laporan keuangan. Adanya pengendalian intern yang baik maka akan tercipta suatu sarana untuk menyusun, mengumpulkan informasi-informasi yang berhubungan dengan transaksi perusahaan, yang secara tidak langsung dapat dijalankan dengan baik pula.

Kebutuhan informasi dalam kondisi persaingan saat ini mendapat perhatian khusus dari pihak manajemen dimana kecepatan dan keamanan informasi yang digunakan merupakan dasar utama bagi manajemen untuk mengantisipasi situasi dan kondisi di dalam maupun di luar perusahaan agar dapat bertindak lebih hati-hati, sehingga mencegah timbulnya kerugian. Penguasaan informasi dapat meningkatkan daya saing perusahaan baik dari segi manajerial atau persaingan pasar dan keberhasilan pimpinan perusahaan dalam menjalankan kewajibannya tergantung dari kemampuan menggunakan informasi yang ada sebagai alat untuk mengambil keputusan. Jadi informasi yang ada dapat digunakan sebagai sumber untuk pengambilan keputusan pembelian, keputusan penjualan, dan keputusan-keputusan lainnya. Informasi digunakan untuk pengambilan keputusan penjualan, yang diharapkan akan membawa perusahaan ke arah laba optimal, serta merupakan alat bantu bagi manajer untuk merumuskan kebijakan yang akan ditempuh, khususnya di bidang penjualan.

Penelitian mengenai perancangan sistem akuntansi khususnya berkaitan dengan penjualan telah dilakukan oleh peneliti sebelumnya. Hasil penelitian Noerlina, dkk. (2010) menyatakan bahwa perusahaan masih menggunakan sistem informasi akuntansi (SIA) penjualan secara manual, sehingga memerlukan SIA penjulan yang terkomputerisasi. Dengan meningkatnya kualitas informasi, maka dapat meningkatkan kualitas pengambilan keputusan. Selain itu sistem dapat mempermudah menajemen dalam mencari informasi penjualan dan penerimaan kas. Temuan penelitian Wandi (2014) menyatakan bahwa Toko Sumber Sthil memerlukan SIA penjualan tunai terkomputerisasi yang memudahkan dalam melakukan pencatatan penjualan tunai yang akurat di bandingkan dengan sistem manual yang digunakan pada Toko Sumber Sthil. Penelitian Irawati (2016) memperoleh temuan bahwa sistem informasi akuntansi penjualan pada PT. Surya Asia Abadi belum berjalan dengan baik. Fungsi, dokumen, prosedur, dan pengendalian internal secara keseluruhan belum berjalan dengan baik. Melisa (2016) memperoleh hasil penelitian yang 
menunjukkan bahwa Sistem informasi akuntansi penjualan spare part pada PT. Top Cars Indonesia Cabang Palembang belum cukup baik. Hasil penelitian Tokan, dkk. (2017) menyatakan bahwa sistem akuntansi penjualan kredit yang diterapkan Dealer sebenarnya masih kurang memadai. Hal ini perlu dilakukan perbaikan sistem agar tidak ada piutang yang tidak tertagih pada bagian penagihan. Dan, terakhir penelitian yang dilakukan oleh Prakasita dan Nugroho (2018) menyatakan bahwa sistem informasi akuntansi penjualan dan persediaan di Central Steak and Coffee masih menggunakan sistem manual.

UD. Galansa Graha Motor Mayang Jember merupakan perusahaan yang bergerak di bidang penjualan sepeda motor bekas. Aktivitas penjualan merupakan hal yang paling penting mengingat perusahaan ini merupakan perusahaan dagang. Perusahaan mampu mencatatkan omset penjualan rata-rata sebesar Rp. 150.000.000,00 sampai Rp. 200.000.000,00 perbulan yang diperoleh dengan penjualan secara tunai. Dengan omset penjualan yang cukup besar perusahaan ini seharusnya menggunakan sistem akuntansi berbasis manual untuk membantu meningkatkan kualitas keamanan aset perusahaan serta meningkatkan kualitas informasi yang efektif dan relevan bagi perusahaan. Berdasarkan hasil observasi terhadap sistem akuntansi penjualan pada UD. Galansa Graha Motor Mayang Jember ditemukan permasalahan diantarnya keamanan data perusahaan tidak terjamin, informasi yang dihasilkan tidak dapat disajikan tepat waktu karena membutuhkan waktu yang lama untuk memproses data menjadi informasi, serta adanya penyalahgunaan kas oleh karyawan perusahaan itu sendiri.

Berkaitan dengan akuntansi penjualan pada UD. Galansa Graha Motor Mayang Jember belum menerapkan sistem akuntansi secara memadai, sehingga peluang untuk terjadinya penyimpangan dinilai masih besar. Aktivitas penjualan masih dilakukan pencatatan secara manual di buku sederhana baik mengenai hasil penjualan maupun unit motor yang terjual. Hal ini tentunya akan berdampak pada pencapaian laba perusahaan, maka diperlukan perancangan mengenai sistem akuntansipenjualan yang mampu menjamin tercapainya pengendalian intern yang baik demi kelangsungan hidup perusahaan. Berdasarkan pemikiran diatas maka peneliti mengambil judul "Perancangan Sistem Akuntansi Penjualan UD. Galansa Graha Motor Mayang Jember".

\section{Metode}

Menurut Arikunto (2013), rancangan penelitian adalah suatu rencana usulan untuk memecahkan masalah sesuai dengan tujuan penelitian. Penulis menggunakan jenis penelitian deskriptif kualitatif dimana data deskriptif berupa kata-kata tertulis atau lisan dari orang-orang dan pelaku yang dapat diamati. Penulis menngunakan data berupa data primer dan data sekunder. Data primer yang digunakan peneltiia adalah data hasil wawancara dengan manajer, kepala bagian keuangan, dan karyawan pada UD. Galansa Graha Motor Mayang Jember. Sedangkan, data sekunder berupa bukti-bukti tulisan (dokumentasi), jurnal-jurnal, laporan-laporan yang ada di UD. Galansa Graha Motor Mayang Jember. Dalam menggumpulkan data, penulis menggunakan metode pengumpulan datadi antaranya wawancara (interview) yang dilakukan terhadap manajer, kepala bagian keuangan, dan karyawan UD. Galansa Graha Motor Mayang Jember terkait dengan sistem akuntansi penjualan. Observasi merupakan teknik yang berbeda dengan wawancara, dimana kalau wawancara dan kueisioner selalu berkomunikasi dengan orang, maka observasitidak terbatas pada orang, tetapi juga objek-objek alam yang lain. Peneliti melakukan observasi bekaitan dengan pelaksanaan prosedur akuntansi yang ada di UD. Galansa Graha Motor Mayang Jember. Penulis juga melakukan dokumentasi dengan melihat faktur penjualan, serah terima penjualan, dan bukti retur penjualan.

Dalam melakukan analisis deskriptif kualitatif atas sistem akuntansi penjualan pada UD. Galansa Graha Motor Mayang Jember dilakukan berkaitan dengan hal-hal sebagai berikut:

a. Teknik pertama

Teknik yang pertama ini adalah melakukan kunjungan pada perusahaan yaitu UD. Galansa Graha Motor Mayang Jember untuk mengetahui keadaan sesungguhnya mengenai kondisi perusahaan, karyawan dan dokumen yang termasuk di dalam sistem penjualan.

b. Teknik kedua

Teknik yang kedua adalah mendeskripsikan sistem akuntansi penjualan tunai yang diterapkan oleh perusahaan yang meliputi prosedur-prosedur, dokumen-dokumen, dan catatan yang dipakai perusahaan UD. Galansa Graha Motor Mayang Jember.

c. Teknik ketiga

Teknik yang ketiga menganalisa kelemahan-kelemahan yang terjadi pada UD. Galansa Graha Motor Mayang Jember. 


\section{d. Teknik keempat}

Teknik yang ke empat adalah membuat rancangan sistem akuntansi penjualan dengan langkahlangkah perancangan meliputi struktur organisasi, prosedur sistem informasi akuntansi penjualan, perancangan flowchart.

Langkah langkah yang akan dilakukan sebagai berikut:

1. Merancang struktur organisasi yang memisahkan tanggung jawab fungsional secara tegas beserta tugas dan wewenangnya.

2. Merancang sistem akuntansi penjualan dengan membuat:

a. Prosedur sistem akuntansi penjualan

b. Flowchart

3. Merancang formulir yang dapat memenuhi kebutuhan pengguna atau pihak manajemen e. Kesimpulan

Penarikan kesimpulan dan rekomendasi rancangan sistem akuntansi yang memadai. Dalam tahap terakhir ini, berdasarkan penjabaran hasil data penelitian dan analisis yang didukung dengan teori - teori dan temuan masalah, penelitian akan menarik kesimpulan sistem yang berjalan apakah sudah memadai atau belum serta memberikan rekomendasi rancangan sistem akuntansi yang memadai.

\section{Hasil dan pembahasan}

\section{A. Sistem Akuntansi Penjualan UD. Galansa Graha Motor Mayang Jember}

Sebagai perusahaan dagang, aktivitas utama dari UD. Galansa Graha Motor Mayang Jember adalah melakukan penjualan sepeda motor bekas. Sehingga, komponen penerimaan kas pada UD. Galansa Graha Motor Mayang Jember berasal dari hasil penjualan sepeda motor kepada konsumen. Adapun deskripsi mengenai sistem penjualan pada UD. Galansa Graha Motor Mayang Jember adalah (Hasil Wawancara dengan Muhamman Niman):

1. Fungsi yang Terkait

Berkaitan dengan aktivitas penjualan sepeda motor bekas yang ada di UD. Galansa Graha Motor Mayang Jember melibatkan beberapa fungsi, yaitu:

a. Fungsi Penjualan

Fungsi ini menjalankan tanggungjawab atas penerimaan pesanan atau order sepeda motor, yang diawali dengan mencatat pesanan, mengisi nota penjualan, selanjutnya menyerhkan nota penjualan tersebut kepada konsumen sebagai bukti pembayaran di bagian kas (kasir). Fungsi ini dijalankan oleh bagian penjualan yang ada di UD. Galansa Graha Motor Mayang Jember.

Fungsi gudang dan penyerahan motor ini masih dijadikan satu dengan fungsi penjualan, mengingat keterbatasan sumber daya manusia dan modal yang ada di UD. Galansa Graha Motor Mayang Jember. Fungsi ini bertanggungjawab menjaga ketersediaan sepeda motor serta penyerahan sepeda motor kepada konsumen. Konsumen yang telah membayar di kasir, dengan menunjukkan bukti pembayaran selanjutnya mengambil sepeda motor yang dibelinya di bagian gudang. Fungsi ini masih dijalankan oleh bagian pemasaran UD. Galansa Graha Motor Mayang Jember.

b. Fungsi Kas

Fungsi kas pada UD. Galansa Graha Motor Mayang Jember dipegang oleh kasir. Bagian kas (kasir) bertanggungjawab untuk menerima pembayaran (penerimaan kas) dari konsumen yang selanjutnya membuat bukti pembayaran yang digunakan oleh konsumen untuk mengambil pesanan atau order sepeda motor di bagian gudang.

2. Informasi yang diperlukan oleh Pihak Manajemen

Manajemen UD. Galansa Graha Motor Mayang Jember memerlukan informasi dalam sistem penjualan diantaranya terkait dengan:

a. Jumlah unit sepeda motor yang siap dijual.

b. Jumlah penerimaan kas dari penjualan sepeda motor bekas.

3. Dokumen yang Digunakan

UD. Galansa Graha Motor Mayang Jember berkaitan dengan penjualan sepeda motor menggunakan dokumen-dokumen dalam sistem akuntansi penjualan adalah:

a. Nota atau Faktur Penjualan

Nota penjualan ini merupakan dokumen yang digunakan untuk merekam data mengenai nomor pemesanan, nama konsumen, pekerjaan konsumen, alamat konsumen, harga, serta informasi terkait identitas sepeda motor diantaranya merek, tahun pembuatan, warna, nomor polisi, nomor chasis, nomor mesin, nomor BPKB. Nota penjualan ini diisi oleh fungsi penjualan yang dilakukan oleh 
bagian penjualan yang selanjutnya menjadi pengantar proses pembelian kepada bagian kas dan manajer.

b. Kwitansi Bukti Pembayaran

Dokumen ini menjadi bukti pembayaran yang dilakukan oleh konsumen kapada bagian kas (kasir). Dokumen ini berisi informasi mengenai nama konsumen (yang melakukan pembayaran), alamat konsumen, jumlah nominal rupiah yang dibayar, dan keperluan (maksud) pembayaran. Dokumen ini digunakan oleh konsumen sebagai bukti pembayaran sepeda motor dan bagi manajer untuk mengecek penerimaan kas di bagian kas (kasir).

\section{Catatan Akuntansi yang Digunakan}

Berkaitan dengan aktivitas penjualan yang ada pada UD. Galansa Graha Motor Mayang Jember, pencatatan masih dilakukan secara manual. Dimana data penjualan yang diterima oleh bagian penjualan hanya dilaporkan kepada manajer, begitu juga penerimaan kas. Dan untuk perhitungan laba rugi perusahaan, manajer melakukan secara sederhana dengan menghitung hasil penjualan dikurangi harga pokok pembelian sepeda motor.

5. Jaringan Prosedur yang Membentuk Sistem

Adapun jaringan prosedur yang membentuk sistem akuntansi penjualan pada UD. Galansa Graha

Motor Mayang Jember yaitu:

a. Prosedur Pesanan atau Order Sepeda Motor

Pembelian sepeda motor bekas pada UD. Galansa Graha Motor Mayang Jember dilakukan dengan konsumen datang ke dealer kemudian melihat dan memilih sepeda motor sesuai dengan keinginan dari konsumen. Sepeda motor yang dipilih konsumen, selanjutnya dapat dipesan atai order di bagian pemasaran.

b. Prosedur Pencatatan Penjualan

Bagian pemasaran yang menerima pesanan atau order sepeda motor, kemudian membuat nota penjualan yang terdiri dari tiga (3) lembar, yaitu pertama, nota penjualan untuk konsumen, kedua nota penjualan untuk kasir, dan ketiga nota penjualan untuk manajer.

c. Prosedur Penerimaan Kas

Konsumen selanjutnya mendatangi bagian kas (kasir) untuk melakukan pembayaran. Kasir akan meminta nota penjualan lembar pertama dan kedua, yang selanjutnya dilakukan crosscheck. Setelah dinilai sesuai, konsumen melakukan pembayaran kepada kasir dan kasir membubuhkan tanda atau cap "lunas" terhadap ketiga lembar nota. Keseluruhan nota tersebut selanjutnya diberikan kepada manajer dan disaat bersamaan manajer memberitahu bagian pemasaran untuk melakukan penyerahan barang.

d. Prosedur Penyerahan Barang

Bagian pemasaran yang menjalankan fungsi penyerahan barang, setelah menerima nota penjualan yang telah ada tanda atau cap "lunas" dan pemberitahuan dari manajer, selanjutnya menyerhkan unit sepeda motor kepada konsumen. 
6. Flowchart Sistem Akuntansi Penjualan

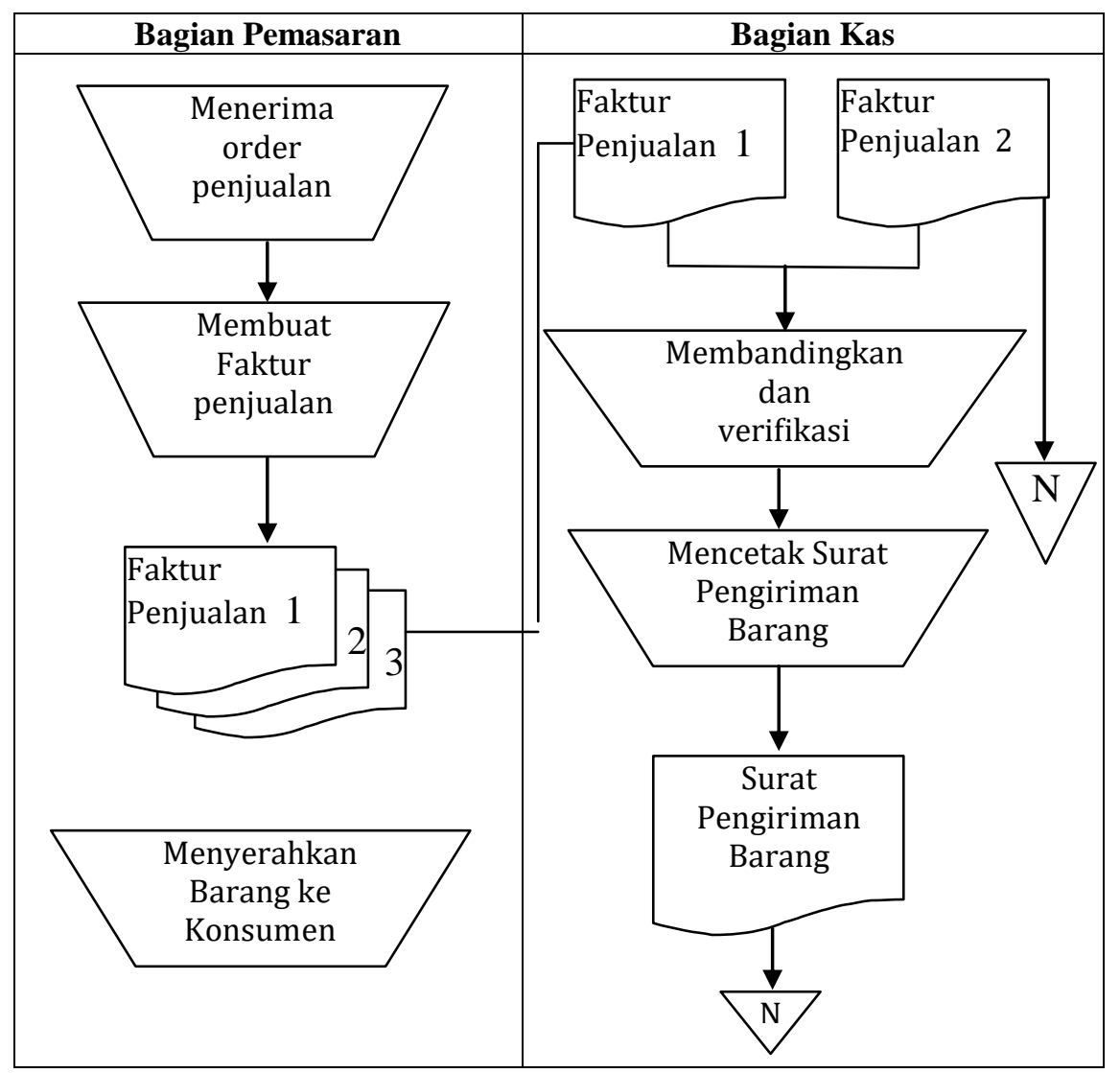

Gambar 1. Bagan Alir Sistem Akuntansi Penjualan pada UD. Galansa Graha Motor Mayang Jember

\section{B. Perancangan Sistem Akuntansi Penjualan UD. Galansa Graha Motor Mayang Jember}

Setelah mengetahui dan mendeskripsikan sistem akuntansi penjualan pada UD. Galansa Graha Motor Mayang Jember, maka peneliti melakukan evaluasi mengenai kesesuaian sistem akuntansi penjualan tersebut antara praktik dan teori. Hal ini dilakukan untuk mengetahui kelemahan dari sistem akuntansi penjualan, sekaligus menjadi dasar untuk perancangan sistem akuntansi penjualan yang dapat direkomendasikan pada UD. Galansa Graha Motor Mayang Jember.

1. Membuat Prosedur Sistem Akuntansi Penjualan Tunai

a. Prosedur Order Penjualan

1) Menerima order dari konsumen

2) Mencetak faktur rangkap 5:

a) Lembar ke-1 konsumen.

b) Lembar ke-2 Bagian Kas

c) Lembar ke-3 Bagian Gudang

d) Lembar ke-4 Bagian Pengiriman

e) Lembar ke-5 Bagian Akuntansi

b. Prosedur Penerimaan Kas

1) Menerima Faktur Penjualan lembar ke-2 kemudian diarsipkan menurut nomer Faktur.

2) Menerima Faktur Penjualan lembar ke-1 dan menerima pembayaran dari konsumen.

3) Membandingkan dan memeriksa Faktur Penjualan lembar 1 dan 2.

4) Memberikan cap lunas pada Faktur Penjualan lembar ke 1 dan menyerahkan kepada konsumen.

5) Mencetak Surat Pengiriman Barang.

6) Mengirimkan Surat Pengiriman Barang ke Bagian Pengiriman.

7) Menerima Surat Pengiriman yang sudah ditanda tangani konsumen dan mengarsipkan secara urut nomer. 
c. Prosedur Gudang

1) Menerima Faktur Penjualan lembar ke-3 dan mengarsipkan urut nomer Faktur.

2) Mengirimkan barang kepada Bagian Pengiriman.

d. Prosedur Penyerahan Barang

1) Menerima Faktur Penjualan lembar ke-4 dari Bagian Pemasaran yang selanjutnya diarsipkan menurut nomer urut Faktur.

2) Menerima sepeda motor dari Bagian Gudang.

3) Menerima Surat Penyerahan Barang dari Bagian Kas.

4) Menyerahkan sepeda motor kepada konsumen disertai Surat Penyerahan Barang untuk ditandatangani oleh konsumen saat sepeda motor diterima.

e. Prosedur Akuntansi

1) Menerima Faktur Penjualan lembar ke-5 dari Bagian Pemasaran.

2) Mencatat transaksi penjualan dari Faktur Penjualan lembar ke-5 ke dalam jurnal umum.

3) Mengarsipkan Faktur Penjualan lembar ke-5 dengan urut nomor.

2. Membuat Flowchart Sistem Akuntansi Penjualan Tunai

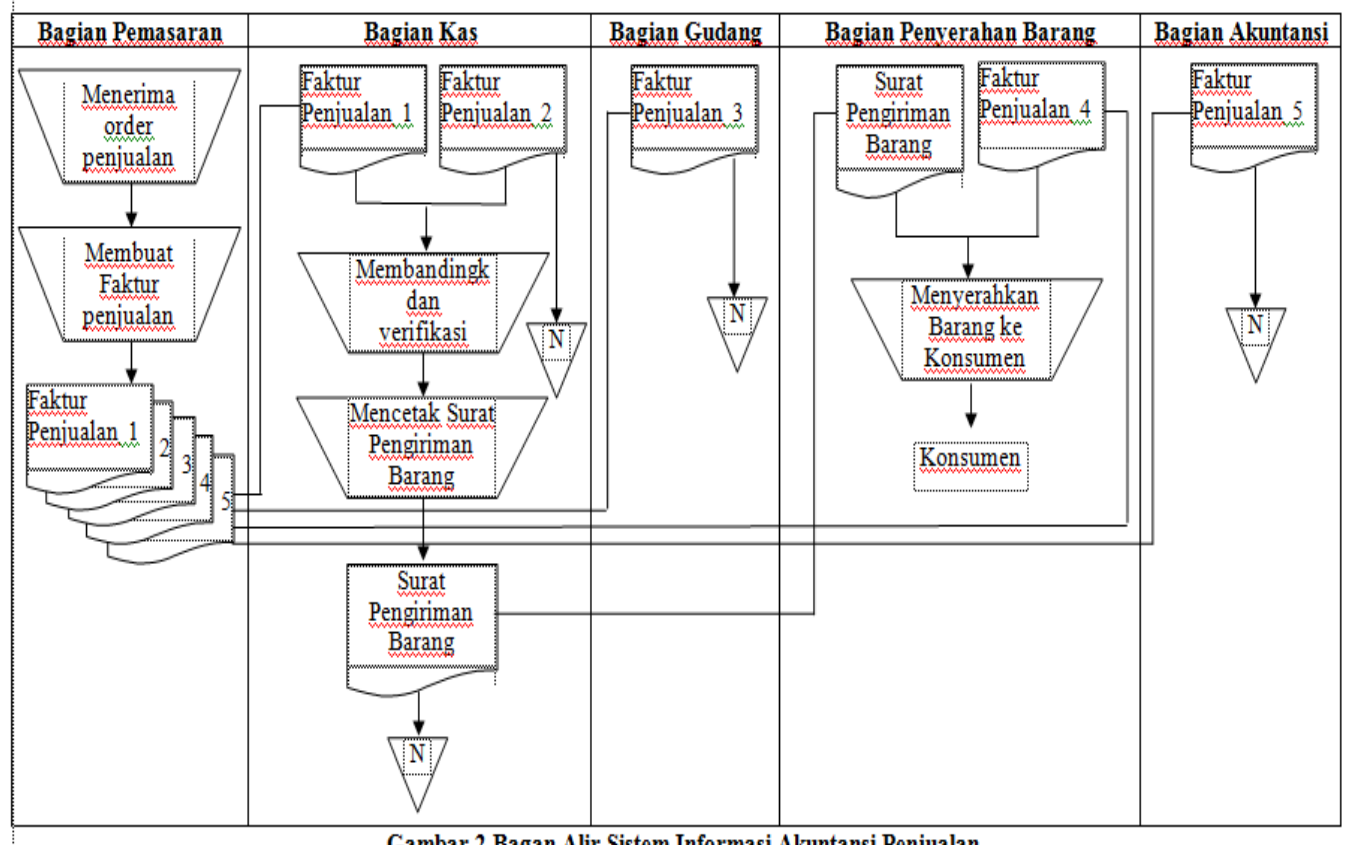

Gambar 2 Bagan Alir Sistem Informasi Akuntansi Penjualan

\section{Simpulan dan saran}

Berdasarkan hasil analisis yang dilakukan maka dapat diperoleh jawaban atas permasalahan penelitian yaitu pertama, UD. Galansa Graha Motor Mayang Jember masih menjalankan sistem akuntansi penjualan secara manual dan dinilai belum memadai. Hal ini dapat dilihat dari belum adanya pemisahan tugas antara fungsi penjualan, fungsi kas, dan fungsi akuntansi. Dokumen dan catatan akuntansi yang digunakan masih sederhana dimana UD. Galansa Graha Motor Mayang Jember hanya menggunakan catatan penjualan. Kedua, perancangan sistem akuntansi penjualan pada UD. Galansa Graha Motor Mayang Jember dilakukan dalam rangka meningkatkan efisiensi dan memenuhi perkembangan aktivitas perusahaan yang semakin kompleks. Perancangan sistem akuntansi penjualan antara lain berupa perancangan struktur organisasi perusahaan, penyusunan prosedur penjualan tunai, dan pembuatan dokumen dan formulir.

Mengacu pada hasil penelitian, maka dapat disusun beberapa saran pertama, bagi pihak manajemen UD. Galansa Graha Motor Mayang Jember kiranya perlu pengembangan sistem akuntansi penjualan yang lebih baik agar efektivitas pengendalian internal dapat tercapai. Dan kedua, bagi penelitian lanjutan dengan tema sejenis, hendaknya melibatkan perusahaan lain yang memiliki kompleksitas usaha, sehingga hasil temuannya akan menambah wawasan yang berkaitang dengan sistem pengendalian internal. 


\section{Daftar Rujukan}

Agoes, Sukrisno. 2014. Auditing Petunjuk Praktis Pemeriksaan Akuntan oleh. Akuntan Publik. Edisi ke 4. Buku 1. Jakarta: Salemba Empat.

Anastasia Diana dan Lilis setiawati. 2010. Perpajakan Indonesia. Yogyakarta: C.V. Andi Offset.

Arikunto, S. 2013. Prosedur Penelitian: Suatu Pendekatan Praktik. Jakarta: Rineka Cipta.

Fitriasari, Dewi.2014. Sistem Informasi Akuntansi. Jakarta: SalembaEmpat.

Hall, James A.2009.Sistem Informasi Akuntansi. Edisi 4. Jakarta: Salemba Empat

Herdianti, Anita. 2011. PenerapanSistemInformasiAkuntansiPenjualanKreditpada PT KaryaLancarMandiriDinamikaKendari.Skripsi.Kendari: UniversitasHaluoleo.

Ikatan Akuntansi Indonesia.2011. Standar Akuntansi Keuangan. Jakarta: Salemba Empat.

Irawati, I. 2016. Analisis Penerapan Sistem Informasi Akuntansi Penjualan pada PT. Surya Asia Abadi Pekanbaru. E-journal Pelita Indonesia.

Krismiaji. 2010. Sistem Informasi Akuntansi. Jogjakarta: UPP AMP YKPN.

Kuncoro, Mudrajad. 2009. Metode Riset Untuk Bisnis \& Ekonomi. Jakarta Penerbit Erlangga.

Melisa. 2016. Analisis Sistem Informasi Akuntansi Penjualan Spare Part pada PT. Top Cars Indonesia Cabang Palembang. Skripsi.Palembang: STIE MDP.

Mulyadi. 2014. Sistem Akuntansi. Cetakan Keempat. Jakarta : Salemba Empat.

Mulyadi. 2015. Akuntansi Biaya, Edisi 5. Yogyakarta : Sekolah Tinggi Ilmu. Manajemen YKPN.

Noerlina, I Gusti Made Karmawan; Nosyar Rahadi. 2010. Analisis Perancangan Sistem Informasi Akuntansi Penjualan dan Penerimaan Kas Pada Perusahaan. ComTech Vol.1 No.2 Desember 2010: 919-927.

Prakasita, Dwijanatri N dan Mahendra Adhi Nugroho. 2018. Perancangan Sistem Informasi Akuntansi Penjualan Dan Persediaan Di Central Steak And Coffee Boyolali. Jurnal Nominal / Volume VII Nomor 1 / Tahun 2018.

Romney, Marshall B. dan Paul John Steinbart. 2014. Sistem Informasi Akuntansi:Accounting Information Systems (Edisi 13).Jakarta: SalembaEmpat.

Sugiyono. 2012. Metode Penelitian Kuantitatif Kualitatif dan R\&D. Bandung: Alfabeta.

Tokan, Elisabeth Priscilia Ilonawati Ina, Tri Lestari, danMashina. 2017. Analisis Penerapan Sistem Informasi Akuntansi Penjualan Kredit dalam Rangka Meningkatkan Pengendalian Intern pada Dealer Toyota Asri Motor Di Sidoarjo. Jurnal Ekonomi Akuntansi Vol. 3. Issue. 3 (2017).

Wandi, Apri (2014) Perancangan Sistem Informasi Akuntansi Penjualan Tunai Pada Toko Sumber Sthil. Skripsi. Semarang: Universitas Dian Nuswantoro Semarang.

Widjajanto, Nugroho. 2011. Sistem Informasi Akuntansi. Jakarta: Erlangga. 